\title{
Avaliaçao Das Condições Higiênico-Sanitárias de Um Empreendimento Solidário de Processamento de Frutas
}

Elisa Cristina Andrade Neves (I), Consuelo Lúcia Sousa De Lima (I), Jesus Nazareno Silva Souza (I), Rafaela Maracajá Colaço (I), Rafaela Barata Alves (I)

(I) UFPA - Universidade Federal do Pará (Rua Augusto Corrêa, 01 - Guamá. CEP 66075-110. Caixa postal 479. )

\section{Resumo}

Os agricultores familiares são responsáveis por grande parte dos alimentos que são postos à mesa dos brasileiros. O incentivo para a instalação de pequenas unidades agroindústrias privadas e cooperativistas tornou-se indispensável para organizar esses agricultores e agregar valor as matériasprimas por eles produzidas e comercializar alimentos seguros através da implantação das Boas Práticas de Fabricação (BPF). O objetivo do trabalho foi avaliar as condições higiênico-sanitárias de uma agroindústria de frutas através da aplicação de uma lista de verificação de BPF e análises microbiológicas. A agroindústria pertence a uma cooperativa formada por agricultores familiares de Abaetetuba (PA), que formam um empreendimento econômico solidário. A lista de verificação utilizada foi baseada na RDC 216 de 15/09/2004 e em todas as amostras de polpa foram realizadas a pesquisa de Salmonella spp, e a contagem de coliformes a $45^{\circ} \mathrm{C}$ e bactérias mesófilas. Os resultados referentes à avaliação das condições higiênico-sanitárias indicaram uma média da porcentagem de itens conformes, obtidas em 3 vistorias, de 32,47\%, classificando o empreendimento no Grupo 3. Em relação à Matéria-prima obteve-se 25,6\%

\footnotetext{
Referência:

Elisa Cristina Andrade neves, Consuelo Lúcia Sousa de Lima, Jesus Nazareno Silva Souza, Rafaela Maracajá Colaço, Rafaela Barata Alves.Avaliaçao Das Condições Higiênico-Sanitárias de Um Empreendimento Solidário de Processamento de Frutas. In: Anais do 12을 Congresso Latinoamericano de Microbiologia e Higiene de Alimentos - MICROAL 2014 [= Blucher Food Science Proceedings, num.1, vol.1]. São Paulo: Editora Blucher, 2014. DOI 10.5151/foodsci-microal-102
} 
de itens conformes, Instalações 42,3\%, Higienização das instalações $32,1 \%$, Manipuladores e higiene pessoal 21,5\%, Processamento de frutas $33,7 \%$, Armazenamento e transporte dos produtos $72,1 \%$ e Controle de qualidade $0 \%$. Verificou-se que pisos, paredes e teto das áreas de produção estavam em adequado estado de conservação, mas não estavam higienizados, ausência de ralos sifonados, luminárias sem proteção, instalações sanitárias desorganizadas, lavatórios com torneiras sem acionamento automático e não possuíam produtos destinados à higiene pessoal, manipuladores sem uniformes completos, recipientes de lixo sem tampas, armazenamento sem controle adequado da temperatura e produtos sem análises para avaliar sua qualidade microbiológica. A polpa de cupuaçu estava dentro do padrão microbiológico estabelecido pela legislação brasileira para todas as análises realizadas. Diferentemente disso, as polpas de abacaxi e o açaí tiveram resultados fora dos padrões para a análise de Coliformes a $45^{\circ} \mathrm{C}$, devido ocorrência de falhas nas etapas de recepção e higienização dos frutos, o que pode acarretar deterioração do produto final, dependendo da eficiência do armazenamento. Portanto, ações corretivas devem ser implantadas para que se atenda aos requisitos das $\mathrm{BPF}$, dentre eles um programa de capacitação dos manipuladores de alimentos.

Palavras-Chave: Boas Práticas de Fabricação, Açaí, Lista de verificação Agência de Fomento: 